\title{
Electoral systems and functioning of the states
}

\author{
Daniela Pastarmadzhieva \\ Department of Political Sciences and National Security, \\ University of Plovdiv Paisii Hilendarski, \\ Bulgaria \\ daniela.pastarmadz̧bieva@uni-plovdiv.bg \\ ORCID 0000-0002-5857-3595
}

Abstract. The electoral system for formation of the legislature has a direct impact on the party system of a state and an indirect one on the stability of the political system, representation of various social groups and partially on the economic performance. Each of the main types of electoral systems (majority/plurality, proportional representation, and mixed systems) consists of subtypes and the results that they produce may vary. Thus, the aim of the current study is to identify if there is an association between the electoral system of a country and its functioning. The object of the research is 176 countries and the focus of the

$$
\begin{array}{r}
\text { Received: } \\
\text { November, 2020 } \\
\text { 1st Revision: } \\
\text { June, 2021 } \\
\text { Accepted: } \\
\text { August, 2021 } \\
\text { DOI: } \\
10.14254 / 2071- \\
8330.2021 / 14-3 / 3
\end{array}
$$
study is their electoral system and a selection of indicators, which demonstrate the performance of the countries. A selection of approaches and methods were used, namely secondary processing of quantitative data, statistical methods such as frequencies, cross tables, chi square, testing hypothesis and comparative analysis. The results show that the electoral system is relevant mostly for the fragility level of the countries. The electoral system didn't prove to be relevant for the income level, unemployment, GDP per capita, group grievance, uneven economic development, refugees and IDPs.

Keywords: electoral system, fragility of the states, unemployment, GDP per capita, income

JEL Classification: D72, K16

\section{INTRODUCTION}

The representativeness of the contemporary democratic political systems has been ensured through regular elections. The most important elections are those for formation of the legislature as the parliament consists of representatives of the society on national level. In almost every democratic political system the legislature is formed through direct national elections. The rights and obligations of citizens related to these elections, as well as the procedures by which they are conducted, are regulated both in the basic law 
- the constitution, and in special election acts. The mentioned regulation in practice determines to what extent the legislative body will reflect the preferences and votes of the citizens.

In each of the three main groups of electoral systems (majority/plurality, proportional representation, and mixed systems) there are various types that produce a different election result (Cortonaet. al, 1987) and each of them has specific advantages and disadvantages. The scientific research based on theory, practice and empirical data clearly demonstrates that none of the electoral systems can be defined as a good or a bad one. Attention must be paid to the particularly important role of the context in which the system is applied and the historical reasons for its introduction.

The electoral system is relevant for a number of areas in the functioning of the country. It is widely accepted and confirmed that the electoral system directly affects the party system (Duverger, 1959; International Institute for Democracy and Electoral Assistance, 2017; Arslantaş et. al., 2020). Furthermore, it has indirect effect on the political stability (Curini \& Martelli, 2009; Ruthrauff, 2017), representation of various social groups (Venice Commission, 2009; Negri, 2018) and, to a limited extent, the functioning of the economy (Acemoglu \& Robinson 2006; Aboal, 2020). However, it should be borne in mind that the effect of the electoral system on the functioning of the state should not be overexposed, as it alone cannot compensate for the weaknesses of the functioning of the democracy (Thomassen, 2014).

Thus, the aim of the current study is to identify if there is an association between the electoral system of a country and some aspects of the evaluation of its functioning. 176 countries are the object of the research. Focus of the study is on their electoral system and a selection of indicators, which demonstrate the performance of the countries. The studied indicators are as follows: Fragility of the state, Security Apparatus, Factionalization of Elites, Grievance of certain social groups, Economic Decline, Uneven economic development, Human Flight and Brain Drain, State Legitimacy, Public Services, Human Rights and Rule of Law, Demographic Pressure, Refugees and IDPs, External Intervention, Unemployment, GDP per capita and Levels of income.

The data used is from The Fund for Peace (Fragile States Index), International Labour Organization (ILOSTAT) and World Bank (Income Grouping). For the identification of the electoral system of a country, data from Inter-Parliamentary Union (IPU) was used. The quantitative data was processed with IBM SPSS Statistics and the methods used included frequencies, cross tables, chi square and testing hypothesis.

The first section of the article is dedicated to the scientific literature on the potential effects of the electoral system on the functioning of a country; the second part presents the methods of the research, and the third consists of the results of the study and discussion of them.

\section{LITERATURE REVIEW}

\subsection{The concept of electoral engineering}

Traditionally, the electoral rules are defined, operationalized and classified according to the way the election result is determined, to the number of deputies in the parliamentary institution and to the structure of the ballot. Furthermore, the results of elections held under different rules can be compared using several indicators, including the ratio of votes cast to seats received, turnout, women's representation, or party pluralism. (Norris, 2004)

The electoral systems can also affect the electoral behaviour, and in particular the party system, the formation of social cleavages, party affiliation and, of course the turnout. To evaluate the effect of the electoral system on numerous areas of the functioning of the states Norris (2004) uses empirical data from 
the Comparative Study of Electoral Systems, the World Bank, the Human Development Index, the InterParliamentary Union, and others. It semd that in her study, Norris uses electoral engineering and electoral reform as synonyms.

As mentioned above the electoral engineering can't enhance the performance of the political system in any case, but it is ascertained that the transformation of electoral rules can contribute to the political stability (Rabkin, 1996; Rahat and Sznajder, 1998; Basedau, 2002), to reduce ethnic tensions (Scholdan, 2000; Fraenkel, 2001; Reilly, 2001; Belschner, 2021) and normalize the post-war environment (Salloukh, 2006; Fraenkel, 2015). There are also examples, when electoral engineering was used by persons or groups to try to ensure victory on the next elections (Turchenko, 2020). The famous case of Elbridge Gerry, who redesigned district boundaries in order to maximize the number of seats his party can receive. His surname and the form of the redesigned district (which is likened to salamander) gave the name to the practice of gerrymandering. The latter means "a distinctively (albeit not uniquely) American practice, that of redrawing district lines to achieve partisan (or other) advantage" (Cox \& Katz, 2002). Nevertheless, there are cases, which demonstrate that the expected results not always are achieved (Manning and Antic, 2003, Belloni, 2004, Golosov, 2014). Similar was the case of Bulgaria in 2009, when the ruling political party introduced a mixed electoral system (parallel) (News, 2009). By that time all the MPs had been elected through closed list proportional representation and it was expected that the new or as they called it "a majority element" would lead to the election of more independent candidates. However, the vote produced quite different result. All of the $31 \mathrm{MPs}$, who were elected through a majority vote, were candidates of a political party and not independent. Most of them (26) were candidates of the new established political party GERB and the political party, which introduced this electoral system received no seats from the majority vote. (Central Electoral Commission of the Republic of Bulgaria, 2009)

Thus, the electoral engineering refers to the implementation of a small or significant change in the electoral rules for the formation of a legislative body to achieve certain goals by those making the changes. The latter can produce positive effect for the society as a whole or benefit single person or a group. Of course, a transformation can also be performed for other types of elections, but most often the notion has been used for the legislative elections. In this sense, the subject of electoral engineering is the legislator or, more precisely, the group dominating the legislature. (Pastarmadzhieva, 2020)

\subsection{Impact of the electoral system on the functioning of a state}

The selection of an electoral system for a state is of particular significance as it can affect various areas of the function of the political system. The impact of the electoral system can be direct or indirect. The results of the electoral rules directly affect the party system and the association has been confirmed by the empirical evidence. However, the procedures for election of MPs indirectly are relevant for the stability of the state, representation of various social groups and to some extent the economic indicators. As concerns the latter it is rather collateral and if there is an association identified it is usually related to numerous other factors as well, including the context.

As concerns the party system according well established Duverger's law the plurality electoral system, which is applied in single-member constituencies and the winner is appointed by simple/relative majority, produces two-party system. It is supplemented by his hypothesis, which states the proportional representation systems and majority systems with second round produce pluralistic party systems (Duverger, 1959). Furthermore, the more centered on the candidate is the electoral system, the more fragmented is the party system. The latter can produce problems in newer democracies, as parties become weaker and thus the democratic system weakens. For instance Thailand, where the majority system Block Vote was introduced led to the fragmentation of the party system (Rocha Menocal, 2011). Mixed systems 
can produce different effects on the party system, depending on how the proportional and majority systems are combined (Blais and Massicotte, 1996).

The political stability of the states is indirectly affected by the electoral system. The stability of the political systems is associated with the absence of violence, the duration of governments, the legitimacy of the political regime, the absence of structural changes and the existence of number of social components (Hurwitz, 1973). The electoral systems is mostly related to the duration of governments and the latter is to high extent connected with the number of political parties, represented in the legislature, especially in the parliamentary regimes. As the majority/plurality systems produce stable one-party governments in most of the cases it leads to improved government efficiency and accountability, and proportional systems are fairer to smaller parties and provide more social representation (Norris, 1997). The majority/plurality systems (and especially the first-past-the-post) are not suitable for societies in which there are significant social contradictions, as they can deepen conflicts by making some social groups less represented (Ortona, 2003). Thus, the coalition governments, produced by the proportional representation, rarely make full term, but their policies can be more sustainable, as it is possible for the same parties to govern in a different coalition format, and can ensure continuity. (Antić and Vlahovec, 2011)

The studies, focused on the association between the electoral system and representation of various social groups, are mainly focused on the representation of ethnic minorities, women and youth. There isn't a unified position which one favors the ethnic minorities representation. On one hand, the Alternative Vote, which is a majority system, offers some incentives to include in the lists candidates from different ethnic minorities (Lublin and Bowler 2018). One the other hand, according to some authors under majority systems, there may be incentives for politicians to polarize the electorate based on ethnic clerics, thus motivating voters to support ethnic parties (Horowitz, 1993). As concerns the proportional systems, they make it possible to compile a balanced list, and usually produce coalition governments in which parties representing ethnic minority groups can also participate (Lublin and Bowler, 2018). The electoral system of Ireland provides such example. The studies focused on the representation of women and youth show that both groups are better represented in countries with proportional representation or mixed systems (Venice Commission, 2009; Inter-Parliamentary Union, 2018; Stockemer\&Sundström, 2018).

As concerns the electoral system and economic development, the statements are usually related to the stability of governments, their efficiency and the continuity of the economic policies. The majority/plurality systems (and especially the British model) provide more stability in terms of full government mandates. The proportional representation on other hand may lead to frequent change of governments and there are studies, which examine the relation between the frequent change of governments and the development of the economy (Alesina et al, 1996; Gurgul\&Lach, 2013). Furthermore, there are economic policies for which a single government mandate is not enough to achieve an effect (Yosifov\&Taneva, 2018; Alexieva\&Angelova, 2020). In this sense, if the political party who governs loses next elections, the new leading political party may suspend its policies and decide to pursue a new course in the economy (Pastarmadzhieva, 2020). The latter may lead to discontinuity in the development of the economy and there is an evidence that the proportional representation may ensure continuity of the economic policies. As concerns the efficiency, it is identified that a more stable government does not necessarily mean a more efficient one. According Antić and Vlahovec (2011) the most objective economic criteria are economic growth, inflation, unemployment and income distribution, and the economic results in turn show the efficiency of the government. However, in coalition governments formed under proportional systems there are certain risks. If one of the coalition partners decides that a proposed policy can cause upheaval, it is very likely for this partner to leave the coalition in order not to accumulate negatives for the next elections. (Antić and Vlahovec, 2011) 


\section{METHODOLOGY}

For the achievement of the purpose of the current research a selection of approaches and methods were used, namely secondary processing of quantitative data, statistical methods such as frequencies, cross tables, chi square, testing hypothesis and comparative analysis. The data is for 2019 and comes from The Fund for Peace (Fragile States Index), International Labour Organization (ILOSTAT), World Bank (Income Grouping). For the identification of the electoral system of a country data from InterParliamentary Union was used, also for 2019.

As a first step of the methodology a dataset in IBM SPSS Statistics was created (Table 1)

Table 1

Variables, included in the SPSS dataset

\begin{tabular}{|c|c|c|}
\hline № & Variable & Description \\
\hline 1 & Country & 176 countries were examined (see Appendix A for the full list) \\
\hline 2 & ElectSystem & The three main types - Majority/Plurality, Proportional, Mixed (IPU, 2019) \\
\hline 3 & Unemployment & $\begin{array}{l}\text { Unemployment rate, measured by the International Labor Organization } \\
\text { Unemployment, total (\% of total labor force) (modeled ILO estimate) }\end{array}$ \\
\hline 4 & GDP & $\begin{array}{l}\text { GDP per capita, measured by the International Labor Organization } \\
\text { GDP per capita (current US\$) }\end{array}$ \\
\hline 5 & Income_group & Income Groups, divided by The World Bank \\
\hline 6 & FSI_Group & Fragile States Index (Group) - Sustainable, Stable, Warning, Alert \\
\hline 7 & FSI_total & Fragile States Index (Total Score) - up to 120 points \\
\hline 8 & FSI_SA & Fragile States Index (Security Aparatus) - up to 10 points \\
\hline 9 & FSI_FE & Fragile States Index (Factionalized Elites) - up to 10 points \\
\hline 10 & FSI_GG & Fragile States Index (Group Grievance) - up to 10 points \\
\hline 11 & FSI_ED & Fragile States Index (Economic Decline) - up to 10 points \\
\hline 12 & FSI_UED & Fragile States Index (Uneven economic development) - up to 10 points \\
\hline 13 & FSI_HFBD & Fragile States Index (Human Flight and Brain Drain) - up to 10 points \\
\hline 14 & FSI_SL & Fragile States Index (State Legitimacy) - up to 10 points \\
\hline 15 & FSI_PS & Fragile States Index (Public Services) - up to 10 points \\
\hline 16 & FSI_HRRL & Fragile States Index (Human Rights and Rule of Law) - up to 10 points \\
\hline 17 & FSI_DP & Fragile States Index (Demographic Pressure) - up to 10 points \\
\hline 18 & FSI_R & Fragile States Index (Refugees and IDPs) - up to 10 points \\
\hline 19 & FSI_EI & Fragile States Index (External Intervention) - up to 10 points \\
\hline
\end{tabular}

Source: made by the author

The IPU provides various data on national parliaments, including the type of electoral system for formation of the legislature. The selection for the purposes of the current study consists of 176 countries because there was available data in both IPU and for at least one of the selected indicators. The data for 2019 was used.

The International Labour Organization (ILO) has a modelled estimates series, including the data for GDP per capita and the unemployment rate. These are made both on official national sources of data and imputed data, where there is no official statistics. Thus, ILO makes possible the comparison of wider range of countries (ILO, 2019b).

The World Bank ranges the countries according to the GNI per capita, namely (The World Bank):

- low-income economies are defined as those with a GNI per capita of $\$ 1,035$ or less in 2019;

- lower middle-income economies are those with a GNI per capita between $\$ 1,036$ and $\$ 4,045$ in 2019; 
- upper middle-income economies are those with a GNI per capita between $\$ 4,046$ and $\$ 12,535$ in 2019;

- high-income economies are those with a GNI per capita of $\$ 12,536$ or more in 2019.

The Fragile states index consists of four groups of indicators - cohesion, economic, political, and social. Cohesion indicators include security threats, the factionalisation of elites, and the division and schisms across social groups. Economic indicators include economic decline and poverty, uneven economic development, loss of human capital and a "brain drain". The group of political indicators includes the legitimacy of the state, the presence of public services, protection of human rights and the rule of law. The social indicators are the pressure of the population on the state on various matters, refugees and internal migration and pressure from outside the country on national matters. Each of these twelve indicators can take values from 0 to 10. In this sense, countries can get a maximum total of 120 points. It should be noted that the more points a country has, the higher its degree of instability. Based on the obtained result, the countries are divided into 4 main categories: Sustainable, Stable, Warning, Alert. (The Fund for Peace, 2017)

\section{EMPIRICAL RESULTS AND DISCUSSION}

The countries included in the dataset use all three types of electoral systems - majority/plurality, proportional and mixed systems. The largest share belongs to those using a proportional electoral system, namely $46 \%$, which is equivalent to 81 countries. The next is the group of countries with majority/plurality electoral systems, including 62 countries or $35 \%$ of all examined. The share of countries with mixed systems is the smallest, namely $19 \%$ or 33 countries that use a mixed system to form the legislature (Figure 1).

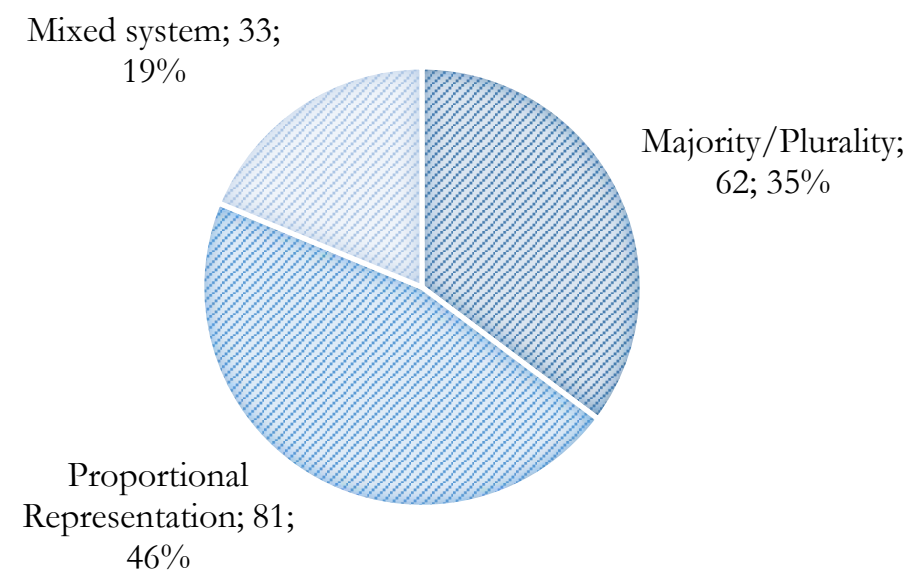

Figure 1. Distribution of types of electoral systems across the studied countries, 2019

Source: Author's calculations based on data from IPU, 2019

As concerns the income groups it is noteworthy that the largest group is the high-income group (55 countries, representing 31\%). The next is the group of upper middle income, which are 52 countries and represent $30 \%$. Lower middle income countries are 48 , which is equal to $27 \%$. The countries with low income are only 21 and this number is equal to $12 \%$ of the studied countries. (Figure 2) 


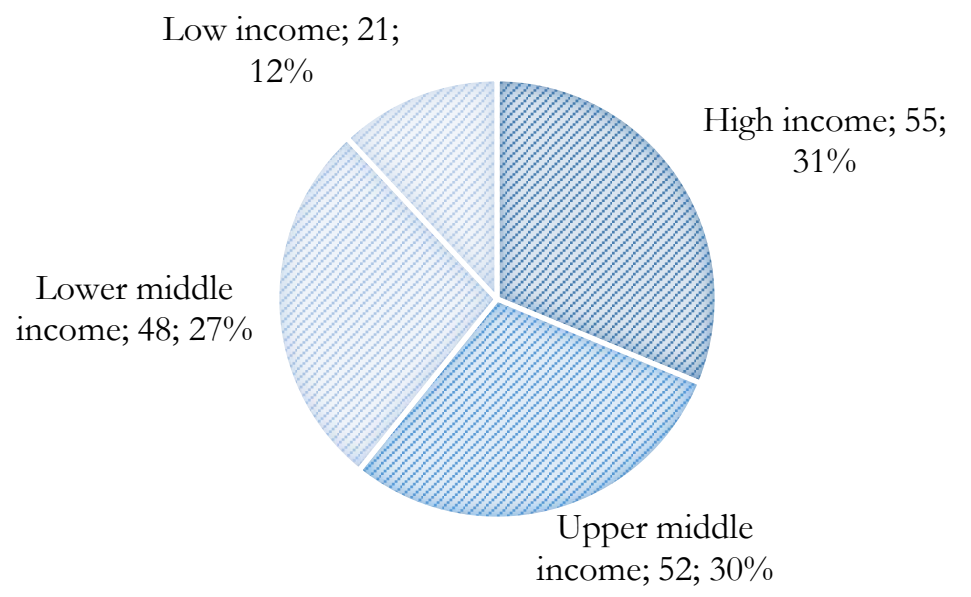

Figure 2. Distribution of income groups across the studied countries, 2019

Source: Author's calculations based on data from the World Bank, 2019

Another important aspect of the research is the status of the countries, regarding their fragility. The largest share of countries are those in warning. They are more than a half of the examined states $(52 \%)$, totally 84 countries. They are followed by the stable countries, which are 36 and represent $23 \%$. The countries in alert are 23 and their share is $14 \%$. The smallest group is the one, consisting of sustainable countries, namely as low as $18(11 \%)$. (Figure 3)

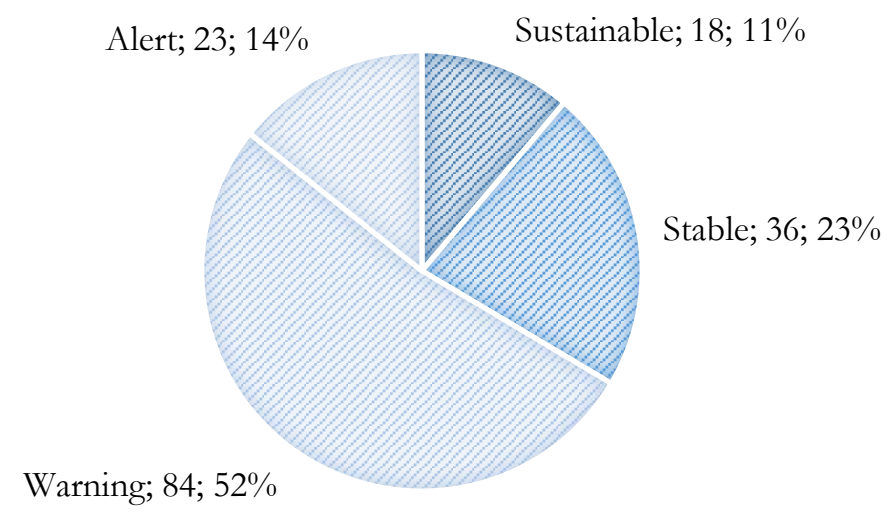

Figure 3. Distribution of fragile states status across the studied countries, 2019

Source: Author's calculations based on data from Fragile States Index, 2019

To identify any associations between the type of electoral system and the level of income cross-tables were used. The results show that the countries with proportional electoral systems are the most in the group with high income, namely $56 \%$ or 31 countries. Their share decreases with the reduction of the income level and in the low-income countries they are only 33\%, which is equal to 7 . The opposite trend is observed regarding the countries using the majority/plurality systems. They are $27 \%$ (15) in high income countries and as much as $43 \%$ in the low-income countries or 9 states. 


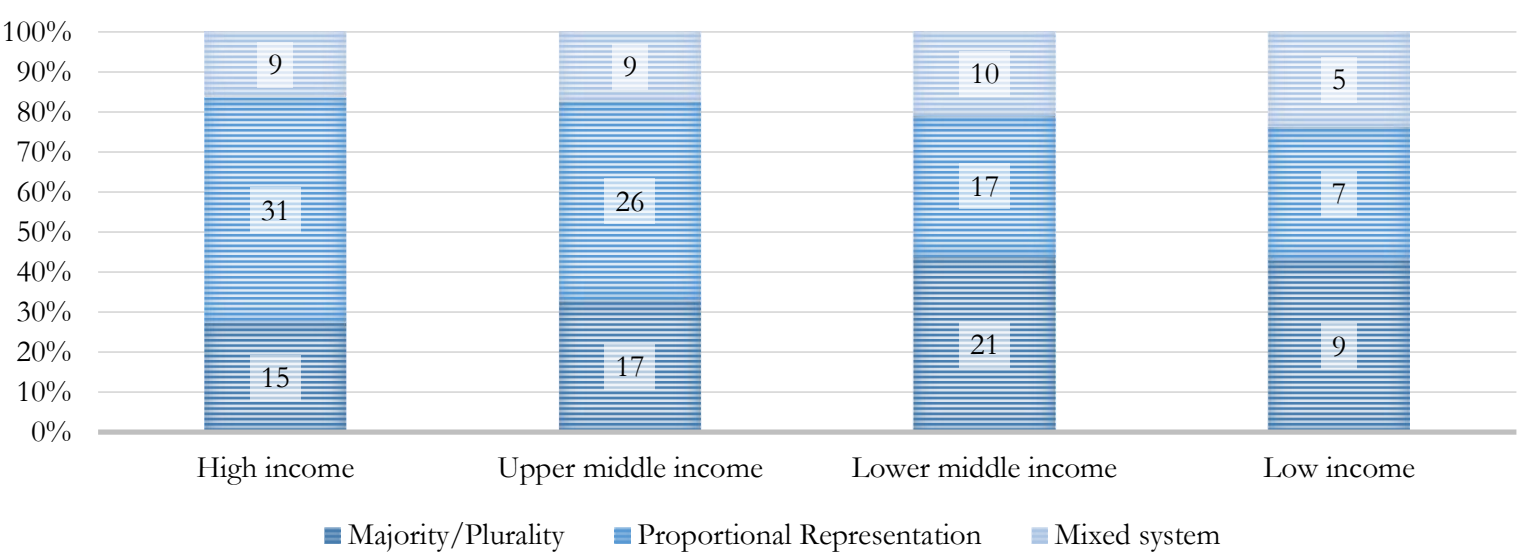

Figure 4. Share of countries with majority/plurality, proportional or mixed systems across the countries with different income levels, 2019

Source: Author's calculations based on data from IPU and the World Bank, 2019

This result gives ground to assume that there is an association between the electoral system type and the income level. To test the assumption the statistical method chi square was used, because the variables are on a nominal scale. The requirements for the application of the method are met, namely the studied cases are over 50 and there are no expected values below 1 and only one below 5, namely 3.94, equal to $8.3 \%$, i.e. less than $20 \%$ (table 2 note). Thus, the chi square test was performed as to whether there was a statistically significant association between the state's electoral system and the income level in the state.

In this sense, the null and alternative hypotheses should be formulated as follows:

$\checkmark \mathrm{H}_{0}$ - there is no statistically significant association between the electoral system and the income level;

$\checkmark \quad \mathrm{H}_{1}$ - there is a statistically significant association between the electoral system and the income level.

To determine the valid hypothesis, it is necessary to compare the value of Asymptotic Significance (2-sided) against Pearson Chi-Square with the probability of error $\alpha=0.05$. In this case, this value is higher, namely 0.379 , therefore the null hypothesis $\mathrm{H}_{0}$ must be accepted as valid. Thus, it can be concluded that at a risk of error of $5 \%$ there is no statistically significant association between the electoral system and the income level. (Table 2)

Table 2

Results of chi square test to identify statistically significant association between the type of electoral system and the income level, 2019

\begin{tabular}{|l|c|c|c|}
\hline \multicolumn{5}{|c|}{ Chi-Square Tests } \\
\hline Pearson Chi-Square & Value & df & Asymptotic Significance (2-sided) \\
\hline Likelihood Ratio & $6,407^{\mathrm{a}}$ & 6 & $\mathbf{0 , 3 7 9}$ \\
\hline Linear-by-Linear Association & 6,471 & 6 & 0,373 \\
\hline N of Valid Cases & 0,564 & 1 & 0,453 \\
\hline a. 1 cells (8,3\%) have expected count less than 5. The minimum expected count is 3,94. \\
\hline
\end{tabular}

Source: Author's own calculations

The data on Figure 5 presents the distribution of electoral system types across the different fragile states status. Cross-tables were used in order to identify any associations between the type of electoral 
system and the fragility status. The results show that the countries with proportional electoral systems have biggest share in the most sustainable countries, namely $78 \%$ or 14 countries. Their share decreases with the increase of country's fragility and in the states in alert they are only $22 \%$, which is equal to 5 . The opposite trend is observed as concerns the majority/plurality systems. They are 17\% (3) in the sustainable states and as much as $57 \%$ in alert states or 13 countries. (Figure 5)

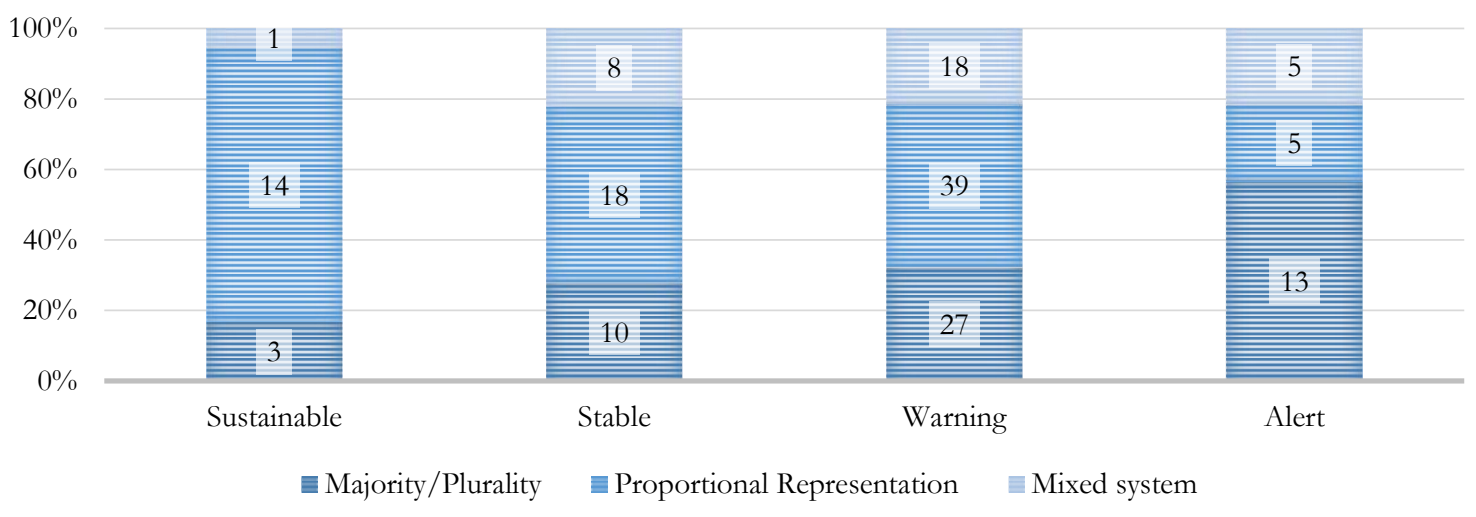

Figure 5. Share of countries with majority, proportional or mixed system across the countries with different fragility status, 2019

Source: Author's calculations based on data from IPU and the Fragile States Index, 2019

Such result gives ground to assume that there is an association between the electoral system type and the fragility status. The method used was also chi square. The requirements for the application of the method are met, namely the investigated cases are over 50 and there are no expected values below 1 and two below 5, equal to $16.7 \%$, i.e. less than $20 \%$ (Table 3 note). Again, the chi square test let us identify if there is a statistically significant association between the state's electoral system and the fragility status.

The null and alternative hypotheses are:

$\checkmark \mathrm{H}_{0}$ - there is no statistically significant association between the electoral system and the fragility status;

$\checkmark \quad \mathrm{H}_{1}$ - there is a statistically significant association between the electoral system and the fragility status.

The next step is to compare the value of Asymptotic Significance (2-sided) against Pearson ChiSquare with the probability of error $\alpha=0.05$. In this case, the value is lower, namely 0.024 , therefore the alternative hypothesis $\mathrm{H}_{1}$ must be accepted as valid. Thus, it can be concluded that at a risk of error of $5 \%$ there is a statistically significant association between the electoral system and the fragility status. (Table 3)

Table 3

Results of chi square test to identify statistically significant association between the type of electoral system and fragility status, 2019

\begin{tabular}{|l|c|c|c|}
\hline \multicolumn{5}{|c|}{ Chi-Square Tests } \\
\hline & Value & df & Asymptotic Significance (2-sided) \\
\hline Pearson Chi-Square & $14,534 \mathrm{a}$ & 6 & $\mathbf{0 , 0 2 4}$ \\
\hline Likelihood Ratio & 15,131 & 6 & 0,019 \\
\hline Linear-by-Linear Association & 1,180 & 1 & 0,277 \\
\hline N of Valid Cases & 161 & & \\
\hline a. 2 cells (16,7\%) have expected count less than 5. The minimum expected count is 3,58. \\
\hline
\end{tabular}

Source: Author's own calculations 
Once a statistically significant association was identified, the strength of this association can be determined. For this purpose, the value of the Cramer's coefficient must be checked. The relevant number is the one in the Value column against Cramer's V. In this case it is 0.212 and as this number is between 0 and 0.3 it means that the association between the electoral system and the fragility of the state is weak. (Table 4)

Strength of the association between the type of electoral system and the fragility status, 2019

\begin{tabular}{|l|l|r|r|}
\hline \multicolumn{3}{|c|}{ Symmetric Measures } \\
\hline \multirow{2}{*}{ Nominal by Nominal } & Phi & Value & Approximate Significance \\
\cline { 2 - 4 } & Cramer's V & 0,300 & 0,024 \\
\hline N of Valid Cases & $\mathbf{0 , 2 1 2}$ & 0,024 \\
\hline
\end{tabular}

Source: Author's own calculations

Regarding the scores of the unemployment, GDP per capita, Fragile States index and its components, other statistical methods can be used, because they have numerical values. Therefore, statistical hypotheses were tested with non-parametric analysis of variance (Kruskal-Wallis test). The purpose of this test was to determine whether there is a significant difference between the countries using majority, proportional and mixed systems in terms of unemployment, GDP per capita, Fragile States index and its components. The hypotheses are formulated as follows:

$\checkmark \quad \mathrm{H}_{0}$ - there is no significant difference between the unemployment, GDP per capita, Fragile States index and its components across the different electoral systems

$\checkmark \quad \mathrm{H}_{1}$ - there is a significant difference between the unemployment, GDP per capita, Fragile States index and its components across the different electoral systems

Table 5

Kruskal-Wallis testing for a statistically significant difference between the unemployment, GDP per capita,

Fragile States index and its components across the different electoral systems, 2019

\begin{tabular}{|c|c|c|c|}
\hline & Kruskal-Wallis H & $\mathrm{df}$ & Asymp. Sig. \\
\hline Unemployment & 1,400 & 2 & 0,497 \\
\hline GDP & 5,363 & 2 & 0,068 \\
\hline Fragile States Index (Total Score) & 8,980 & 2 & 0,011 \\
\hline Fragile States Index (Security Apparatus) & 7,498 & 2 & 0,024 \\
\hline Fragile States Index (Factionalized Elites) & 6,171 & 2 & 0,046 \\
\hline Fragile States Index (Group Grievance) & 1,311 & 2 & 0,519 \\
\hline Fragile States Index (Economic Decline) & 6,358 & 2 & 0,042 \\
\hline Fragile States Index (Uneven economic development) & 5,738 & 2 & 0,057 \\
\hline Fragile States Index (Human Flight and Brain Drain) & 7,526 & 2 & 0,023 \\
\hline Fragile States Index (State Legitimacy) & 8,519 & 2 & 0,014 \\
\hline Fragile States Index (Public Services) & 8,577 & 2 & 0,014 \\
\hline Fragile States Index (Human Rights and Rule of Law) & 17,794 & 2 & 0,000 \\
\hline Fragile States Index (Demographic Pressure) & 11,588 & 2 & 0,003 \\
\hline Fragile States Index (Refugees and IDPs) & 3,114 & 2 & 0,211 \\
\hline Fragile States Index (External Intervention) & 8,098 & 2 & 0,017 \\
\hline
\end{tabular}

Source: Author's own calculations

To determine which of the two hypotheses is valid, a comparison should be made between the value of Asymp. Sig against each indicator and the probability of error $\alpha=0.05$. As can be seen from Table 5 there are two groups: 
1) As concerns the unemployment, GDP per capita, group grievance, uneven economic development, refugees and IDPs the value of Asymp. Sig is higher than $\alpha=0.05$. This means that the electoral system is not relevant for their assessment.

2) For the total score of Fragile States Index, the security apparatus, factionalized elites, economic decline, human flight and brain drain, state legitimacy, public services, human rights and rule of law and demographic pressure the value of Asymp. Sig is lower than $\alpha=0.05$. This means that the alternative hypothesis for these indicators should be accepted as valid. Thus, we can conclude that there is a significant difference between the countries' assessments on total score of Fragile States Index, the security apparatus, factionalized elites, economic decline, human flight and brain drain, state legitimacy, public services, human rights and rule of law and demographic pressure, based on the type of electoral system that they use. (Table 5). To identify which system performs better the mean values have to be seen. (Table 6).

Table 6

Mean values of the studied indicators in the three groups of electoral systems, 2019

\begin{tabular}{|c|r|r|r|}
\hline Type of electoral system (Group) & $\begin{array}{c}\text { Majority/ } \\
\text { Plurality }\end{array}$ & $\begin{array}{c}\text { Proportional } \\
\text { Representation }\end{array}$ & $\begin{array}{c}\text { Mixed } \\
\text { system }\end{array}$ \\
\hline Fragile States Index (Total Score) & 71,52 & $\mathbf{5 9 , 7 2}$ & 70,53 \\
\hline Fragile States Index (Security Apparatus) & 5,83 & $\mathbf{4 , 9 6}$ & 6,13 \\
\hline Fragile States Index (Factionalized Elites) & 6,71 & $\mathbf{5 , 8 9}$ & 6,96 \\
\hline Fragile States Index (Economic Decline) & 5,87 & $\mathbf{5 , 0 9}$ & 5,74 \\
\hline Fragile States Index (Human Flight and Brain Drain) & 6,13 & $\mathbf{5 , 1 6}$ & 5,44 \\
\hline Fragile States Index (State Legitimacy) & 6,28 & $\mathbf{5 , 0 3}$ & 6,22 \\
\hline Fragile States Index (Public Services) & 5,78 & $\mathbf{4 , 4 4}$ & 5,26 \\
\hline Fragile States Index (Human Rights and Rule of Law) & 6,23 & $\mathbf{4 , 4 9}$ & 5,90 \\
\hline Fragile States Index (Demographic Pressure) & 6,10 & $\mathbf{4 , 6 0}$ & 5,67 \\
\hline Fragile States Index (External Intervention) & 6,06 & $\mathbf{4 , 8 5}$ & 5,96 \\
\hline
\end{tabular}

Source: Author's own calculations

As can be seen in Table 6 as regards all of the indicators the proportional electoral systems have a lower score than the majority/plurality and mixed ones. Thus, the countries with proportional systems have a better result in terms of the fragility and of the components of the index, listed in the table 6 , and the difference with countries with majority/plurality and mixed systems can be defined as significant in the examined year, namely 2019.

\section{CONCLUSION}

The empirical data for 2019 provide evidence to conclude that the electoral system is relevant mostly for the fragility level of the countries. It is definitely relevant for the fragility status and for the evaluation of most of the Fragile States Index components, including security apparatus, factionalized elites, economic decline, human flight and brain drain, state legitimacy, public services, human rights and rule of law and demographic pressure. However, the association between the electoral system and the fragility status is low and such result corresponds to the scientific literature, reviewed in the beginning of this study.

Although initially it looked like that the electoral system is relevant for the income level, the chi square test gave evidence to conclude that there is no statistically significant association between the electoral system and the income level. It was also identified that the electoral system is not relevant for the unemployment, GDP per capita, group grievance, uneven economic development, refugees and IDPs. 
The result confirms the conclusions of other scholars about the limited impact of the electoral system on various economic indicators.

Thus, it can be concluded that the electoral engineering may affect to a limited extent some aspects of the functioning of the states, but this is not valid for the economic performance. The current results show that the electoral system is not relevant for the economy of the states. However, the obtained results don't mean that the type of electoral system is responsible for the good or bad functioning of the states.

The results of the current research draw the attention to the limited effect, which electoral system has on the performance of the countries. The legislators must be cautious when making transformations in the electoral rules in their attempt to achieve specific results. The latter must be considered carefully because there are areas for which the electoral system is not relevant as the results of the current study demonstrates. The current research can be used as a starting point for further investigation using more indicators, in dynamics and also by studying specific cases.

\section{ACKNOWLEDGEMENT}

The article is funded by Fund "Scientific research" at the University of Plovdiv Paisii Hilendarski.

\section{REFERENCES}

Aboal, D. (2020). Electoral systems and economic growth, Economia Politica, 37, 781-805, https://doi.org/10.1007/s40888-020-00185-6

Acemoglu, D., Robinson, J. A. (2006). Economic Origins of Dictatorship and Democracy. New York: Cambridge University Press

Alesina, A., Ozler, S, Roubini, N. \& Swagel, P. (1996). Political instability and economic growth. Journal of Economic Growth, 1(2), 189-211

Alexieva, V. \& Angelova, M. (2020) Opportunities for Raising the Entrepreneurial Culture a Factor for Competitiveness of the Bulgarian Economy, International Journal of Entrepreneurship and Small Business 40(3), 373398, DOI: 10.1504/IJESB.2019.10014160

Antić, M. \& Vlahovec, J. (2011). To Eat a Cake and to Have a Three-Quarter of It: Is It Possible to Have the Best of Both Worlds of Electoral Systems. Anali Hrvatskog politološkog drustua, 8(1), 73-92

Arslantaş, D., Arslantaş, Ş. \& Kaiser, A. (2020). Does the Electoral System Foster a Predominant Party System? Evidence from Turkey. Swiss Polit Sci Rev, 26(1), 125-143. https://doi.org/10.1111/spsr.12386

Basedau, M. (2002). On the Link between Electoral System, and Democratic Stability in Africa. Critical Remarks on the Potential of Electoral Engineering. Africa Spectrum, 37(3), 311-333

Belloni, R. (2004). Peacebuilding and consociational electoral engineering in Bosnia and Herzegovina. International Peacekeeping, 11(2), 334-353. doi:10.1080/1353331042000237300

Belschner, J. (2021). Electoral Engineering in New Democracies: Strong Quotas and Weak Parties in Tunisia. Government and Opposition, 1-18. Cambridge University Press.

Blais, A. \& Massicotte, L. (1996). Mixed electoral systems: An overview. Representation, 33, 115-118

Central Electoral Commission of the Republic of Bulgaria (2009) Results of the elections for MPs in 2009, Retrieved from https://pi2009.cik.bg/elected/rik_00.html, (06.09.2020)

Cortona, P.G.D., Manzi, C., Pennisi, A., Ricca, F. \& Simeone, B. (1987). Evaluation and optimization of electoral systems. Philadelphia: Society for Industrial and Applied Mathematics

Cox, G. W. \& Katz, J. N. (2002) Elbridge Gerry's Salamander. The Electoral Consequences of the Reapportionment Revolution, Cambridge: Cambridge University Press

Curini, L. \& Martelli, P. (2009). Electoral Systems and Government Stability: A Simulation of 2006 Italian Policy Space. AUCO Crech Economic Review, 3, 305-322

Duverger, M. (1959). Political Parties: Their Organization and Activity in the Modern State. Second English Revised edn. London: Methuen \& Co 
European Commission for Democracy through Law (Venice Commission) (2009). Report on the impact of electoral systems women's representation in politics, Retrieved from: https://www.venice.coe.int/webforms/documents/default.aspx?pdffile=CDL-AD(2009)029-e (03.09.2020)

Fraenkel, J. (2001). The Alternative Vote System In Fiji: Electoral Engineering Or Ballot-Rigging? Commonwealth \& Comparative Politics, 39(2), 1-31. doi:10.1080/713999545

Fraenkel, J. (2015). Equality of Rights for Every Civilised Man South of the Zambezi: Electoral Engineering in Southern Rhodesia, 1957-65. Journal of Southern African Studies, 41(6), 1167-1180. doi:10.1080/03057070.2015.1116231

Fund for Peace (2019) Fragile States Index Annual Report 2019, Retrieved from: https://fundforpeace.org/wpcontent/uploads/2019/04/9511904-fragilestatesindex.pdf (17.06.2020)

Golosov, G. V. (2014). Authoritarian Electoral Engineering and its Limits: A Curious Case of the Imperiali Highest Averages Method in Russia. Europe-Asia Studies, 66(10), 1611-1628. doi:10.1080/09668136.2014.967553

Gurgul, H. \& Lach, L. (2013) Political instability and economic growth: Evidence from two decades of transition in CEE, Communist and Post-Communist Studies, 46(2), 189-202

Horowitz, D. L. (1993). Democracy in Divided Societies. Journal of Democracy, 4(4), 18-38

Hurwitz, L. (1973) Contemporary Approaches to Political Stability.Comparative Politics, 5(3), 449-463

International Institute for Democracy and Electoral Assistance (2017) Elections, Electoral Systems and Party Systems, Stockholm: International IDEA, Retrieved from: https://www.idea.int/gsod-2017/files/IDEA-GSOD2017-RESOURCE-GUIDE-ELECTIONS.pdf (30.07.2021)

International Labor Organization(2019a) ILO Modelled Estimates, November 2019, ILOSTAT, Research Department and Statistics Department, ILO. Retrieved from: https://ilostat.ilo.org/data/ (18.09.2020)

International Labor Organization (2019b) The Global Labour Income Share and Distribution, Methodological description, Retrieved from https://www.ilo.org/ilostat-files/Documents/Labour\%20income $\% 20$ share $\% 20$ and $\%$ 20distribution.pdf (18.09.2020)

Inter-Parliamentary Union (2018) Youth participation in national parliaments, Geneva, Switzerland: Inter-Parliamentary Union, Retrieved from: https://www.ipu.org/file/6076/download?token=7Aog71dH (06.09.2020)

Inter-Parliamentary Union. Global Data on National Parliaments, https://data.ipu.org/ Retrieved September 16, 2020

Lublin, D. \&Bowler, S. (2018). Electoral Systems and Ethnic Minority Representation, In Erik S. Herron, Robert J. Pekkanen and Matthew S. Shugart (eds). The Oxford Handbook of Electoral Systems (pp. 159-174), New York, USA: Oxford University Press

Manning, C. L. \& Antic, M. (2003). The Limits of Electoral Engineering. Journal of Democracy, 14(3), 45-59. doi:10.1353/jod.2003.0057

Negri, M. (2018) Preferential votes and minority representation in open list proportional representation systems, Soc Choice Welf, 50, pp 281-303, https://doi.org/10.1007/s00355-017-1084-2

News (2009). BSP predlaga smesena izbiratelna sistema, Retrieved from https://news.bg/politics/bsp-predlagasmesena-izbiratelna-sistema.html (06.09.2020)

Norris, P. (1997). Choosing Electoral Systems: Proportional, Majoritarian and Mixed Systems. International Political Science Review, 18, 297-312

Norris, P. (2004). Electoral Engineering: Voting Rules and Political Behavior. Cambridge: Cambridge University Press

Ortona, G. (2003). Choosing the Electoral System: Why Not Simply the Best One? POLIS Working Papers 30, Institute of Public Policy and Public Choice - POLIS.

Pastarmadzhieva (2020).The majority/plurality system and the development of the societies, Sofia: Publishing House of Knowledge Society Institute

Rabkin, R. (1996). Redemocratization, Electoral Engineering, and Party Strategies in Chile 1989-1995. Comparative Political Studies, 29(3), 335-356. doi:10.1177/001041409602900300

Rahat, G. \& Sznajder, M. (1998). Electoral engineering in Chile: the electoral system and limited democracy. Electoral Studies, 17(4), 429-442. doi:10.1016/s0261-3794(98)00001-8

Reilly, B. (2001). Democracy in Divided Societies: Electoral Engineering for Conflict Management. Cambridge: Cambridge University Press 
Rocha Menocal, A. (2011). Why Electoral Systems Matter: An Analysis of their Incentives and Effects on Key Areas of Governance. London: Overseas Development Institute (ODI)

Ruthrauff, H. (2017). The electoral reforms in three association countries of the Eastern Neighbourbood -Ukraine, Georgia and Moldova and their impact on political developments in these countries, Brussels: Policy Department, Directorate-General for External Policies, doi:10.2861/466168

Salloukh, B. F. (2006). The Limits of Electoral Engineering in Divided Societies: Elections in Postwar Lebanon.Canadian Journal of Political Science, 39(3), 635-655, doi:10.1017/s0008423906060185

Scholdan, B. (2000). Democratisation and Electoral Engineering in Post-Ethnic Conflict Societies. Javnost - The Public, 7(1), 25-40. doi:10.1080/13183222.2000.11008733

Stockemer, D. \& Sundström, A.(2018) Age representation in parliaments: Can institutions pave the way for the young? European Political Science Review, 10(3), 467-490.

The Fund for Peace (2017) Fragile States Index Methodology and Cast Framework, https:/ / fragilestatesindex.org/2017/05/13/fragile-states-index-and-cast-framework-methodology/, Retrieved September 18, 2020

The World Bank (n.d.). World Bank Country and Lending Groups, Retrieved from: https://datahelpdesk.worldbank.org/knowledgebase/articles/906519-world-bank-country-and-lendinggroups (20.09.2020)

Thomassen, J. (2014). Elections and Democracy: Representation and Accountability, New York, USA: Oxford University Press

Turchenko, M. (2020). Electoral Engineering in the Russian Regions (2003-2017), Europe-Asia Studies, 72(1), pp. 8098, DOI: $10.1080 / 09668136.2019 .1682522$

Yosifov, T. \& Taneva, G. (2018). A model for assessing economic risk in financing innovation projects of venture capital funds, Ikonomicheski Izsledvania 27(4), 146-161 


\section{APPENDIX A}

Full list of the states and territories, included in the dataset

\begin{tabular}{|c|c|c|c|c|c|c|c|}
\hline 1. & Albania & 45. & Dominica & 89. & Lesotho & 133. & Rwanda \\
\hline 2. & Algeria & $\begin{array}{l}46 . \\
\text { Rep }\end{array}$ & $\begin{array}{l}\text { Dominican } \\
c\end{array}$ & 90. & Liberia & $\begin{array}{l}134 . \\
\text { Nevis }\end{array}$ & Saint Kitts and \\
\hline 3. & Andorra & 47. & Ecuador & 91. & Libya & 135. & Saint Lucia \\
\hline 4. & Angola & 48. & Egypt & 92. & Liechtenstein & $\begin{array}{l}136 . \\
\text { the } G\end{array}$ & $\begin{array}{l}\text { Saint Vincent and } \\
\text { ladines }\end{array}$ \\
\hline $\begin{array}{l}5 . \\
\text { Barl }\end{array}$ & Antigua and & 49. & El Salvador & 93. & Lithuania & 137. & Samoa \\
\hline 6. & Argentina & $\begin{array}{l}50 . \\
\text { Gui }\end{array}$ & Equatorial & 94. & Luxembourg & 138. & San Marino \\
\hline 7. & Armenia & 51. & Estonia & 95. & Madagascar & $\begin{array}{l}139 . \\
\text { Princi }\end{array}$ & Sao Tome and \\
\hline 8. & Australia & 52. & Eswatini & 96. & Malaysia & 140. & Senegal \\
\hline 9. & Austria & 53. & Ethiopia & 97. & Maldives & 141. & Serbia \\
\hline 10. & Azerbaijan & 54. & Fiji & 98. & Mali & 142. & Seychelles \\
\hline 11. & Bahamas & 55. & Finland & 99. & Malta & 143. & Sierra Leone \\
\hline 12. & Bahrain & 56. & France & 100. & Marshall Islands & 144. & Singapore \\
\hline 13. & Bangladesh & 57. & Gabon & 101. & Mauritania & 145. & Slovakia \\
\hline 14. & Barbados & 58. & Gambia & 102. & Mauritius & 146. & Slovenia \\
\hline 15. & Belarus & 59. & Georgia & 103. & Mexico & 147. & Solomon Islands \\
\hline 16. & Belgium & 60. & Germany & 104. & Micronesia & 148. & South Africa \\
\hline 17. & Belize & 61. & Ghana & 105. & Monaco & 149. & Spain \\
\hline 18. & Benin & 62. & Greece & 106. & Mongolia & 150. & Sri Lanka \\
\hline 19. & Bhutan & 63. & Grenada & 107. & Montenegro & 151. & Suriname \\
\hline 20. & Bolivia & 64. & Guatemala & 108. & Morocco & 152. & Sweden \\
\hline $\begin{array}{l}21 . \\
\text { Her }\end{array}$ & $\begin{array}{l}\text { Bosnia and } \\
\text { vina }\end{array}$ & 65. & Guinea & 109. & Mozambique & 153. & Switzerland \\
\hline 22. & Botswana & 66. & Guinea-Bissau & 110. & Myanmar & 154. & Tajikistan \\
\hline 23. & Brazil & 67. & Guyana & 111. & Namibia & 155. & Thailand \\
\hline 24. & Bulgaria & 68. & Haiti & 112. & Nauru & 156. & Timor-Leste \\
\hline 25. & Burkina Faso & 69. & Honduras & 113. & Nepal & 157. & Togo \\
\hline 26. & Burundi & 70. & Hungary & 114. & Netherlands & 158. & Tonga \\
\hline 27. & Cabo Verde & 71. & Iceland & 115. & New Zealand & $\begin{array}{l}159 . \\
\text { Tobas }\end{array}$ & Trinidad and \\
\hline 28. & Cambodia & 72. & India & 116. & Nicaragua & 160. & Tunisia \\
\hline 29. & Cameroon & 73. & Indonesia & 117. & Niger & 161. & Turkey \\
\hline 30. & Canada & 74. & Iran & 118. & North Macedonia & 162. & Turkmenistan \\
\hline 31. & Chad & 75. & Iraq & 119. & Norway & 163. & Tuvalu \\
\hline 32. & Chile & 76. & Ireland & 120. & Pakistan & 164. & Uganda \\
\hline 33. & Colombia & 77. & Israel & 121. & Palau & 165. & Ukraine \\
\hline 34. & Comoros & 78. & Italy & 122. & Panama & 166. & United Kingdom \\
\hline 35. & Congo & 79. & Jamaica & $\begin{array}{l}123 . \\
\text { Guine }\end{array}$ & Papua New & $\begin{array}{l}167 . \\
\text { of } \mathrm{Ta}\end{array}$ & $\begin{array}{l}\text { United Republic } \\
\text { nia }\end{array}$ \\
\hline 36. & Costa Rica & 80. & Japan & 124. & Paraguay & $\begin{array}{l}168 . \\
\text { Amer }\end{array}$ & United States of \\
\hline
\end{tabular}




\begin{tabular}{|c|c|c|c|c|c|c|c|}
\hline 37. & Côte d'Ivoire & 81. & Jordan & 125. & Peru & 169. & Uruguay \\
\hline 38. & Croatia & 82. & Kazakhstan & 126. & Philippines & 170. & Uzbekistan \\
\hline 39. & Cyprus & 83. & Kenya & 127. & Poland & 171. & Vanuatu \\
\hline 40. & Czechia & 84. & Kiribati & 128. & Portugal & 172. & Venezuela \\
\hline $\begin{array}{l}41 . \\
\text { Peo } \\
\text { Ko }\end{array}$ & $\begin{array}{l}\text { Democratic } \\
\text { Republic of }\end{array}$ & & Kyrgyzstan & $\begin{array}{l}129 . \\
\text { Kor }\end{array}$ & Republic of & 173. & Viet Nam \\
\hline $\begin{array}{l}42 . \\
\text { Rep }\end{array}$ & $\begin{array}{l}\text { Democratic } \\
\text { c of the Congo }\end{array}$ & $\begin{array}{l}86 . \\
\text { Det }\end{array}$ & $\begin{array}{l}\text { Lao People's } \\
\text { ratic Republic }\end{array}$ & $\begin{array}{l}130 . \\
\text { Molc }\end{array}$ & Republic of & 174. & Yemen \\
\hline 43. & Denmark & 87. & Latvia & 131. & Romania & 175. & Zambia \\
\hline 44. & Djibouti & 88. & Lebanon & $\begin{array}{l}132 . \\
\text { Fede }\end{array}$ & $\begin{array}{l}\text { Russian } \\
\text { on }\end{array}$ & 176. & Zimbabwe \\
\hline
\end{tabular}

